\title{
PENYESUAIAN DAN PERUBAHAN AKTA ANGGARAN DASAR YAYASAN
}

\author{
Lalu Irwan Suryadi \\ Mahasiswa Magister Hukum Fakultas Hukum Universitas Mataram, NTB, Indonesia \\ Email:laluirwanmih@gmail.com
}

\section{Muhammad Sood}

Fakultas Hukum Universitas Mataram, Mataram, NTB, Indonesia

Email:muhammadsoodfh@unram.ac.id

\begin{abstract}
Abstrak
Penelitian ini bertujuan Untuk mengetahui dan menganalisis pengaturan perubahan akta angaran dasar yayasan berdasarkan peraturan perundang-undangan yang berlaku dan dasar pertimbangan hakim dalam mengadili dan memutus perkara Nomor 25/PDT. G/2017/PN. Pya tentang perubahan anggaran dasar yayasan. Penelitian ini merupakan penelitian hukum normatif dengan menggunakan Pendekatan perundang-undangan (statute approach), Pendekatan konspetual (conceptual approach) dan Pendekatan kasus (case approach). Hasil penelitian menunjukkan bahwa Perubahan akta pendirian Yayasan setelah keluarnya Undang-Undang Nomor 16 Tahun 2001 junto Undang-Undang Nomor 28 Tahun 2004 tentang Yayasan dimaksudkan agar Yayasan yang sudah ada sebelum lahirnya UU Yayasan supaya memiliki status sebagai badan hukum yang sama dengan Yayasan yang didirikan setelah keluarnya UU Yayasan tersebut. Adapun dasar pertimbangan hakim bahwa yang menjadi dalil gugatan para Penggugat adalah mengenai adanya perbuatan melawan hukum yang dilakukan oleh para Tergugat atas terbitnya Akta Yayasan No. 16 tertanggal 18 Desember 2015 yang dibuat oleh Tergugat XII dan pengesahan yayasan dari Tergugat XIII Menteri Hukum Dan Hak Asasi Manusia Republik Indonesia yaitu pada tanggal 11 Desember 2015 dengan No. Surat Keputusan AHU-0030613.AH.01.04. tentang Pendirian Badan Hukum Yayasan Pondok Pesantren al Ma-Arif Uswatu Hasanah, sementara akta tersebut adalah sudah dibatalkan oleh Notaris Natatmadja dan Akta Sah atas Penyesuaian dan Perubahan Anggaran Dasar Yayasan Pondok Pesantren Uswatun Hasanah dan kepengurusannya tertuang dalam akta No. 26 tanggal 10 Desember 2015 yang terdapat Lampiran Surat Keputusan nama Yayasan Pondok Pesantren Al- MA'ARIF Uswatu Hasanah, dengan hal ini menyebabkan gugatan para Penggugat kabur maka dengan demikian eksepsi Tergugat I s/d Tergugat XI yang menyakatan gugatan para Penggugat kabur adalah beralasan hukum untuk dikabulkan.
\end{abstract}

\section{Kata Kunci: Penyesuaian; Perubahan Anggaran Dasar, Yayasan.}

\section{Abstract}

This study aims to determine and analyze the arrangements for amendments to the basic budget deeds of the foundation based on the prevailing laws and regulations and the basis for judges' considerations in adjudicating and deciding cases Number 25 / PDT. G / 2017 / PN. Pya regarding the amendments to the foundation's articles of association. This research is a normative legal research using a statutory approach (statute approach), a conceptual approach (conceptual approach) and a case approach (case approach). The results showed that the amendment to the founding deed of a Foundation after the issuance of Law Number 16 of 2001 in conjunction with Law Number 28 of 2004 concerning Foundations was intended so that foundations that existed before the birth of the Foundation Law had the same status as a foundation established after the issuance of the Foundation Law. As for the basis for the judge's consideration that the argument for the Plaintiff's lawsuit was regarding the existence of illegal acts committed by the Defendants upon the issuance of the Deed of Foundation No. 16 dated 18 December 2015 made by Defendant XII and legalization of the foundation from Defendant XIII, the Minister of Law and Hum Rights of the Repulic of Indonesia, nam on 11 December 2015 with No

156 Lalu Irwan Suryadi \& Muhammad Sood | Penyesuaian dan Perubahan Akta... 
Decree AHU-0030613.AH.01.04. concerning the Establishment of a Legal Entity for the Al Ma-Arif Uswatu Hasanah Islamic Boarding School Foundation, while the deed has been canceled by Notary Natatmadja and the Legal Deed of Adjustments and Amendments to the Articles of Association of the Uswatun Hasanah Islamic Boarding School Foundation and its management as stated in deed No. 26 dated 10 December 2015, which contained the attachment to the Decree on the name of the Uswatu Hasanah Al-MA'ARIF Islamic Boarding School Foundation, with this causing the Plaintiffs 'lawsuit to run away, thus the exceptions of Defendant I to Defendant XI who claimed that the Plaintiffs' claim was run was based on law. to be granted.

Keywords: Adjustment; Amendments to the Articles of Association; Foundation.

\section{A. PENDAHULUAN}

Sebelum adanya undang-undang yang mengatur tentang yayasan, yayasan hanya merupakan alat yang secara fungsional menjadi sarana untuk hal-hal atau pekerjaan dengan tujuan sosial, kebudayaan, dan ilmu pengetahuan. Dengan diundangkannya Undang Undang Yayasan, maka pengertian yayasan menjadi lebih jelas. Sedangkan persyaratan yang ditentukan agar yayasan dapat diperlakukan dan memperoleh status sebagai badan hukum adalah pendirian yayasan sebagai badan hukum harus mendapat pengesahan oleh Menteri Hukum dan Hak Asasi Manusia.

Dalam Peraturan Menteri Hukum dan Hak Asasi Manusia Nomor 6 Tahun 2014 Tentang Pengesahan Badan Hukum Perkumpulan yang dimaksud dengan perkumpulan adalah "badan hukum yang merupakan kumpulan orang didirikan untuk mewujudkan kesamaan maksud dan tujuan tertentu di bidang sosial, keagamaan, dan kemanusiaan dan tidak membagikan keuntungan kepada anggotanya".

Akta pendirian adalah tidak mutlak, apabila ada akta pendirian, maka biasanya dibuat dihadapan Notaris atau dalam bentuk otentik, kemudian dapat didaftarkan dalam Register di Kantor Panitera Pengadilan Negeri dimana perkumpulan tersebut berkedudukan. Para pengurus apabila tidak diatur lain dalam anggaran dasarnya, berwenang bertindak atas nama perkumpulan, mengikat perkumpulan didalam dan diluar pengadilan. Para Pengurus harus dapat menunjukkan bahwa diri mereka berwenang bertindak atas nama perkumpulan. ${ }^{1}$

Apabila dalam Anggaran Dasar tidak terdapat ketentuan mengenai kepengurusan perkumpulan, maka tidak seorangpun anggota perkumpulan yang berwenang bertindak atas nama perkumpulan. Namun ketentuan ini tidak berlaku apabila tindakan tersebut memberi manfaat bagi perkumpulan. ${ }^{2}$

Dengan terbitnya Peraturan Menteri Hukum dan Hak Asasi Manusia Nomor 6 Tahun 2014 tentang Pengesahan Badan Hukum Perkumpulan yang merinci pengertian Perkumpulan, membuat adanya keterkaitan Perkumpulan dengan yayasan.

Keterkaitan definisi yayasan dengan definisi perkumpulan terdapat pada tujuan badan hukum yaitu sama-sama bergerak dibidang sosial, keagamaan dan kemanusiaan. Perbedaannya bahwa yayasan adalah badan hukum terdiri atas kekayaan yang dipisahkan dari kekayaan para pendirinya sedangkan perkumpulan pada hakikatnya adalah kumpulan orang bertujuan tidak mencari keuntungan. Disamping itu yayasan merupakan badan hukum yang tidak memiliki anggota sedangkan badan hukum perkumpulan merupakan kumpulan orang, artinya mempunyai anggota.

\footnotetext{
'Pasal 1655 KUHPerdata: "Para Pengurus suatu perkumpulan adalah sekedar tentang itu tidak telah diatur secara lain dalam surat pendiriannya, perjanjian-perjanjiannya dan regelemen-reglemennya, berkuasa untuk bertindak atas nama perkumpulan, mengikat perkumpulan kepada orang-orang pihak ketiga dan sebaliknya, begitu pula bertindak di muka Hakim, baik sebagai penggugat maupun tergugat".

${ }^{2}$ Pasal 1656 KUHPerdata: "Segala perbuatan, untuk mana para pengurusnya tidak berkuasa melakukannya, hanyalah mengikat perkumpulan sekedar perkumpulan itu sungguh-sungguh telah mendapat manfaat karenanya atau sekedar perbuatan-perbuatan itu tekemudian telah disetujui secara sah."
} 
Yayasan dan perkumpulan sebagai badan hukum merupakan "artificial person" (orang ciptaan hukum) yang hanya dapat melakukan perbuatan hukum dengan perantaraan manusia selaku wakilnya. Yayasan dan perkumpulan sangat tergantung pada wakil-wakilnya dalam melakukan perbuatan hukum, karenanya agar yayasan dan perkumpulan dapat dengan mudah melakukan perbuatan hukum tersebut yayasan dan perkumpulan harus mempunyai organ. Ketiadaan organ menyebabkan yayasan dan perkumpulan tidak dapat berfungsi dan mencapai maksud dan tujuan pendiriannya.

Dengan diterbitkannya peraturan Menteri Hukum dan Hak Asasi Manusia Nomor 6 Tahun 2014 Tentang Pengesahan Badan Hukum Perkumpulan, maka pelayanan hukum dibidang pemesanan nama dan pengesahan badan hukum Perkumpulan sudah meninggalkan cara manual atau konvensional dan sudah beralih secara elektronik (online system).

Untuk mendapatkan pengesahan, maka harus diajukan permohonan kepada Menteri Hukum dan Hak Asasi Manusia. Pemohon yang dimaksud disini adalah setiap orang baik secara sendiri-sendiri maupun bersama-sama yang secara langsung memberikan kuasa kepada notaris untuk mengajukan permohonan kepada Sistem Administrasi Badan Hukum (SABH). Sistem Administrasi Badan Hukum adalah sistem pelayanan administrasi badan hukum secara elektronik yang diselenggarakan oleh Direktorat Jenderal Administrasi Hukum Umum, Kementerian Hukum dan Hak Asasi Manusia Republik Indonesia. Untuk permohonan pengesahan badan hukum Perkumpulan yang diajukan oleh Pemohon kepada Menteri Hukum Dan Hak Asasi Manusia harus melalui tahapan awal yaitu dengan mengajukan nama perkumpulan secara elektronik (online system) melalui SABH. Pemesanan nama perkumpulan, oleh negara tidak dipungut biaya apapun, tetapi untuk permohonan pengesahan badan hukum perkumpulan akan dibebankan biaya sesuai ketentuan peraturan perundang-undangan yang berlaku.

Adapun dokumen pendirian disimpan oleh notaris, yang meliputi Akta pendirian yang dikeluarkan oleh notaris, yang memuat anggaran dasar dan anggaran rumah tangga; Program kerja; Sumber pendanaan; Surat keterangan domisili yang diketahui lurah/kepala desa; Nomor Pokok Wajib Pajak atas Nama perkumpulan; dan Surat Pernyataan yang menyatakan tidak sedang dalam sengketa kepengurusan atau dalam perkara dipengadilan.

Sebelum keluarnya Peraturan Menteri Hukum dan Hak Asasi Manusia Nomor 6 Tahun 2014 Tentang Pengesahan Badan Hukum Perkumpulan dan Undang Undang Nomor 17 Tahun 2013 Tentang Organisasi Masyarakat, pembuatan akta badan hukum perkumpulan dilakukan oleh Notaris berlandaskan Staadsblad 1870 No.64 Tentang PerkumpulanPerkumpulan Berbadan Hukum, perkumpulan diartikan sebagai kumpulan orang yang diatur dalam Buku Ketiga Bab Kesembilan Kitab Undang Undang Hukum Perdata (Burgerlijke Wetboek 1848) pasal 1653 hingga pasal 1665.

Meskipun secara normative terdapat regulasi yang mengatur secara khusus masing-masing badan hukum tersebut yaitu Yayasan diatur melalui Undang-Undang Nomor 16 tahun 2001 jo UU No. 28 tahun 2004 tentang Yayasan (UU Yayasan) dan Perkumpulan yang diatur dengan Peraturan Menteri Hukum dan Hak Asasi Manusia Nomor 3 Tahun 2016 tentang Tata Cara Pengajuan Permohonan Pengesahan Badan Hukum dan Persetujuan Perubahan Anggaran Dasar Perkumpulan ("Permenkumham 3/2016") akan tetapi didalam praktek seringkali menimbulkan kekaburan norma khususnya terkait dengan prosedur perubahan anggaran dasar nya, bahkan tidak menutup kemungkinan menimbulkan perselisihan diatara para pendiri.

Hal ini misalnya tercermin dalam kasus Perkara Nomor 25/PDT. G/2017/PN.Pya yang berawal dari adanya konflik pribadi diantara anggota Yayasan yang merasa tidak terima pengurus yayasan yang bersangkutan di berhentikan dari kepengurusan Yayasan melalui rapat luar biasa para pendiri Yayasan. 
Dari pemaparan materi di atas dapat diuraikan beberapa permasalah sebagai berikut:

1. Bagaimanakah pengaturan perubahan akta anggaran dasar yayasan berdasarkan peraturan perundang-undangan yang berlaku?

2. Apa dasar pertimbangan hakim dalam mengadili dan memutus perkara Nomor 25/PDT. G/2017/PN.Pya tentang perubahan anggaran dasar yayasan?

\section{B. METODE PENELITIAN}

Penelitian ini merupakan penelitian hukum normative (legal resesrch) dengan menggunakan metode pendekatan perundang-undangan (statute approach), pendekatan konseptual (conceptual approach) dan pendekatan Kasus atau Casse approach.

\section{PEMBAHASAN}

\section{Pengaturan Perubahan Anggaran Dasar Yayasan Sebagai Badan Hukum}

\section{a. Yayasan sebagai Badan Hukum}

Suatu badan dikatakan mempunyai atribut sebagai badan hukum apabila Undang-Undang menetapkan atau menyatakan demikian. Ada beberapa syarat agar suatu badan usaha atau perkumpulan dapat disebut sebagai badan hukum terkait dengan sumber hokum khususnya sumber hukum formal, yaitu :

1. Syarat berdasarkan ketentuan perUndang-Undangan

2. Syarat berdasar pada hukum kebiasaan dan yurisprudensi

3. Syarat berdasar pada pandangan doktrin

Syarat berdasarkan ketentuan perUndang-Undangan yaitu berdasarkan ketentuan Pasal 1653 KUHPerdata terdapat 2 (dua) cara yaitu $:^{3}$

1. Dinyatakan dengan tegas bahwa suatu organisasi adalah merupakan badan hukum

2. Tidak dinyatakan secara tegas tetapi dengan peraturan sedemikian rupa bahwa badan itu adalah badan hukum. oleh karena itu, dengan peraturan dapat ditarik kesimpulan bahwa badan itu adalah badan hukum

Dalam perkembangan yurisprudensi Indonesia dicapai suatu pendapat Pengadilan Negeri yang menyatakan bahwa pengesahan sebagai badan hukum dari Menteri Kehakiman adalah syarat mutlak bagi berdirinya suatu perseroan terbatas sebagaimana tertera dalam Putusan Pengadilan Negeri Semarang No. 224/1950/Perdata, tertanggal 17 Maret 1951. ${ }^{4}$

Syarat berdasarkan hukum kebiasaan dan yurisprudensi digunakan apabila tidak ditemukan syarat-syarat badan hukum dalam peraturan perundang- undangan dan doktrin karena hukum kebiasaan dan yurisprudensi merupakan sumber hukum formal. Menurut hukum kebiasaan dan yurisprudensi, suatu badan hukum dikatakan ada apabila terdapat pemisahan kekayaan, ada penunjukan suatu tujuan tertentu, dan ada penunjukan suatu organisasi tertentu.

Salah satu contoh tentang penentuan badan hukum melalui yurisprudensi adalah yayasan. Putusan Mahkamah Agung No. 124K/Sip/1973 tanggal 27 Juni 1973 tentang kedudukan suatu yayasan sebagai badan hukum dalam kasus Yayasan Dana Pensiun HMB. Keputusan lainnya adalah Putusan Mahkamah Agung No. 476 K/Sip/1975 tanggal 8 Mei 1975 tentang kasus perubahan Wakaf Al Is Af menjadi Yayasan Al Is Af. Sehingga berdasarkan hukum kebiasaan dan yurisprudensi suatu badan dikatakan sebagai badan hukum apabila memenuhi syarat materiil

\footnotetext{
${ }^{3}$ Anwar Borahima.(2011).Kedudukan Yayasan di Indonesia : Eksistensi, Tujuan, dan Tanggung Jawab Yayasan. Jakarta: Kencana, hlm. 23.

${ }^{4}$ Ibid., hlm. 24.
} 
dan syarat formil. Syarat materiil agar dikatakan sebagai badan hukum adalah harus adanya pemisahan kekayaan, tujuan, dan pengurus, sedangkan syarat formil adalah didirikan dengan akta autentik. Setelah adanya Undang-Undang Yayasan, pengesahan dan pengumuman merupakan syarat yang harus dipenuhi oleh yayasan.

Menurut Subekti, badan hukum adalah "suatu badan atau perkumpulan yang dapat memiliki hak-hak dan melakukan perbuatan seperti seorang manusia serta memiliki kekayaan sendiri dapat digugat atau menggugat didepan hakim"s. Kemudian menurut Rachmat Soemitro mendefinisikan badan hukum (rechtpersoon) sebagai "suatu badan yang dapat mempunyai harta, hak, serta kewajiban seperti orang pribadi"6. Wirjono Projodikoro berpendapat bahwa badan hukum adalah "badan yang disamping manusia perseorangan juga dianggap dapat bertindak dalam hukum dan yang mempunyai hak-hak, kewajiban-kewajiban, dan perhubungan hukum terhadap orang lain atau badan lain?

Badan hukum diberi status oleh hukum sebagai "persoon" yang mempunyai hak dan kewajiban badan hukum sebagai pembawa hak dapat melakukan tindakkan sebagai pembawa hak manusia yaitu badan hukum dapat melakukan persetujuan. Persetujuan tersebut memiliki kekayaan yang sama sekali terlepas dari kekayaan anggotanya ${ }^{8}$.

Yayasan dengan tujuan khusus seperti "keagamaan dan pendidikan" sudah sejak lama pula ada. Lebih dari seribu tahun sebelum lahirnya Nabi Isa, para Pharaoh telah memisahkan sebagian kekayaannya untuk tujuan keagamaan. Xenophon mendirikan yayasan dengan cara menyumbangkan tanah dan bangunan untuk kuil bagi pemujaan kepada Artemis, pemberian makanan dan minuman bagi yang membutuhkan, dan hewan-hewan korban. Plato, pada saat menjelang kematiannya pada tahun 347 sebelum masehi, memberikan hasil pertanian dari tanah yang dimilikinya untuk disumbangkan selama-lamanya bagi academia yang didirikannya. Ini mungkin merupakan yayasan pendidikan pertama di dunia9.

Hal tersebut memperlihatkan bahwa lebih dari seribu tahun sebelum masehi tokoh-tokoh sosial dan kemanusiaan di masa lalu telah menerapkan prinsip-prinsip universal yayasan. "Di Belanda yayasan (stichtingen) ini pada tahun 1956 barulah diatur dengan Wet op Stichtingen van 31 Mei 1956, yang mulai berlaku pada tanggal 1 Januari 1957"10. "Namun pada tahun 1882 Belanda telah memiliki yurisprudensi tentangyayasan"11.

Salah satu contoh yurisprudensi tentang yayasan sebagai badan hukum adalah :

Putusan Mahkamah Agung tanggal 27 Juni 1973 Nomor 124 K/SIP/1973 telah mempertimbangkan kedudukan suatu yayasan sebagai badan hukum, di mana dalam pertimbangan putusannya tersebut Mahkamah Agung telah membenarkan putusan Judex Factie bahwa Yayasan Dana pensiun H.M.B. didirikan di Jakarta dengan nama "Stichting Pensiunfonds H.M.B. Indonesie" dan bertujuan untuk menjamin keuangan para anggotanya. Bahwa para anggotanya ialah pegawai NV. H.M.B., mempunyai pengurus sendiri terlepas dari NV. H.M.B., dan yayasan tersebut mempunyai harta sendiri, antara lain harta benda hibah dari NV. H.M.B. (Akte Hibah). Bahwa dengan demikian yayasan tersebut merupakan suatu badan hukum. ${ }^{12}$ Keputusan lainnya adalah Putusan Mahkamah Agung No. 476K/Sip/1975,

\footnotetext{
${ }^{5}$ Subekti.( 2013). Pokok-Pokok Hukum Perdata. Jakarta: PT. Inter Masa, hlm. 182

${ }^{6}$ Rachmat Soemitro.(2011). Penuntutan Perseroan Terbatas dengan Undang- undang Pajak Perseroan. Bandung: PT. Eresco, hlm. 36.

${ }^{7}$ Wirjono Projodikoro.( 2011). Azas-azas Hukum Perdata. Bandung: Sumur Bandung, hlm. 84.

${ }^{8}$ C.S.T. Kansil dan Christine Kansil, Op.cit, hlm.9

${ }^{9}$ Chatamarrasyid.(2012). Tujuan Sosial Yayasan dan Kegiatan Usaha Bertujuan Laba. Bandung: Citra Aditya Bakti, hlm. 1.

${ }^{10}$ Pitlo, Het.(2011). Nederlands Burgelijke Wet Boek deel 1 A, Het Rechts Personenrecht. B.V. Arnhem: Gouda Quint, hlm. 7.

${ }^{11}$ Gatot Supramono.(2008). Hukum Yayasan di Indonesia. Jakarta: Rineka Cipta, hlm. 3.

${ }^{12}$ C. Ali.(2011). Badan Hukum. Bandung: Alumni, hlm. 91
} 
tanggal 8 Mei 1975, tentang kasus perubahan Wakaf Al Is Af menjadi Yayasan Al Is Af. ${ }^{13}$

Sebelum berlakunya Undang-Undang Yayasan, tidak ada satupun peraturan perUndangUndang an yang mengatur secara khusus tentang Yayasan di Indonesia. Selain itu, tampak di masyarakat bahwa peranan yayasan di berbagai sektor, misalnya di sektor sosial, pendidikan dan agama sangat menonjol. Oleh karena itu lembaga tersebut hidup dan tumbuh berdasarkan kebiasaan yang hidup di dalam masyarakat. Namun demikian, tidaklah berarti bahwa di Indonesia sama sekali tidak ada ketentuan yang mengatur tentang yayasan.

Secara sporadik di beberapa Undang-Undang disebut adanya yayasan, seperti ;Pasal 365, Pasal 899, 900, 1680 KUHPerdata, kemudian dalam Pasal 6 ayat (3), dan Pasal 236 Rv, serta Pasal 2 ayat (7) Undang-Undang Kepailitan (Faillissements-verordening). ${ }^{14}$ Selain itu, di dalam Peraturan Menteri (Permen Penerangan Republik Indonesia No. 1/Per/Menpen/1969 tentang pelaksanaan mengenai kententuan-ketentuan mengenai Perusahaan Pers, dalam Pasal 28 disebutkan, bahwa untuk perusahaan yang bergerak di bidang penerbitan Pers harus berbentuk badan hukum. Yang dianggap sebagai badan hukum oleh Permen tersebut adalah Perseroan Terbatas (PT), Koperasi, atau Yayasan. Di dalam beberapa ketentuan tentang perpajakan juga disebutkan tentang yayasan. Di dalam berbagai peraturan perUndang-Undangan agraria, dimungkinkan pula bagi yayasan untuk memiliki hak atas tanah. ${ }^{15}$ "Bahkan sejak tanggal 25 Agustus 1961, telah dibentuk yayasan dana Landreform oleh Menteri Agraria sebagai pelaksana dari Peraturan Pemerintah Nomor 224 Tahun 1961." 16

Dalam praktek hukum yang berlaku di Indonesia pada umumnya yayasan selalu didirikan dengan akta Notaris sebagai syarat untuk terbentuknya suatu yayasan. Di dalam akta Notaris dimuat ketentuan tentang pemisahan harta kekayaan oleh pendiri yayasan, yang kemudian tidak boleh dikuasai lagi oleh pendiri. Akta Notaris ini tidak didaftarkan ke Pengadilan Negeri, dan tidak pula dimumkan dalam Berita Negara. "Para pengurus yayasan tidak diwajibkan untuk mendaftarkan dan mengumumkan akta pendiriannya, juga tidak disyaratkan pengesahan dari Menteri Kehakiman sebagai tidakan preventif"'17.

Tidak adanya ketentuan hukum yang dapat digunakan untuk mengatur yayasan ini menimbulkan kecenderungan di masyarakat untuk menggunakan yayasan sebagai tempat untuk menampung kekayaan para pendiri, pengelola yayasan atau pihak lain, tidak lagi sebagai badan usaha yang sifatnya nirlaba atau tidak mencari keuntungan. Ketiadaan peraturan yang jelas ini kemudian juga berdampak pada semakin cepatnya pertumbuhan yayasan di Indonesia yang tidak diikuti oleh pertumbuhan peraturan mengenai yayasan di Indonesia, sehingga terjadi penafsiran mengenai yayasan secara sendiri-sendiri oleh masyarakat yang berkepentingan sesuai dengan kebutuhan dan tujuan mereka.

Sering kali kita jumpai Yayasan yang mengalami masalah karena kurang terampil dan terdidiknya Sumber Daya Manusia Yayasan, sehingga kegiatan yayasan semakin lama semakin berkurang bahkan menjadi tidak aktif sama sekali dan akhirnya yang tinggal hanyalah papan namanya saja. Selain itu, tidak jarang juga kita jumpai suatu yayasan yang berkembang dengan baik dan mendapatkan laba, kemudian mulai terjadi ketidaksepakatan intern di antara pengurus yang mengakibatkan terjadi sengketa, sehingga harus meminta penyelesaian melalui lembaga peradilan.

Menyadari hal tersebut, akhirnya setelah 56 tahun Indonesia merdeka pemerintah baru mengeluarkan Undang-Undang yang mengatur tentang yayasan pada tanggal 6 Agustus 2001,

\footnotetext{
${ }^{13}$ Anwar Borahima.(2011). Kedudukan Yayasan di Indonesia : Eksistensi, Tujuan dan Tanggung Jawab Yayasan. Jakarta: Kencana, $\operatorname{hlm} 24$.

${ }^{14}$ Ibid., hlm.1.

${ }^{15}$ Rudi Prasetya.(2013). Kedudukan Mandiri Perseroan Terbatas. Bandung: Citra Aditya Bakti, hlm. 35.

${ }^{16}$ Boedi Harsono.(2018). Hukum Agraria Indonesia, Sejarah Pembentukan Undang-Undang Pokok Agraria, Isi, dan Pelaksanaannya, Jilid I Hukum Tanah Nasional. Jakarta: Djambatan, hlm. 320.

${ }^{17}$ Anwar Bohima, op.cit., hlm.4
} 
yaitu Undang-Undang Nomor 16 Tahun 2001 Lembaran Negara (LN) No. 112 Tahun 2001 Tambahan Lembaran Negara (TLN) 4132 yang mulai berlaku 1 (satu) tahun terhitung sejak tanggal diundangkan yaitu tanggal 6 Agustus 2002 dan kemudian telah mengalami revisi dalam beberapa pasalnya dengan disahkannya Undang-Undang Nomor 28 tahun 2004 tentang Perubahan atas Undang-Undang No 16 Tahun 2001 tentang Yayasan LN No. 115 TLN

4430. Dalam keterangan pemerintah dihadapanparipurna Dewan Perwakilan Rakyat mengenai Rancangan Undang-Undang Yayasan tanggal 26 Juni 2000, dijelaskan bahwa penyusunan Undang-Undang yayasan dilandasi oleh beberapa pokok pikiran, yaitu :

1) Untuk memenuhi kebutuhan perkembangan hukum dalam masyarakat mengenai pengaturan tentang yayasan.

2) Untuk menjamin kepastian serta ketertiban hukum serta berfungsinya yayasan sesuai dengan maksud dan tujuannya berdasarkan prinsip keterbukaan dan akuntabilitas bagi masyarakat dalam mendirikan yayasan. Disamping itu, untuk memberikan pemahaman serta kejelasan kepada masyarakat mengenai maksud, tujuan, dan fungsi yayasan sebagai pranata hukum dalam rangka mencapai tujuan yayasan.

3) Berkaitan dengan arahan yang terdapat dalam Garis-Garis Besar Haluan Negara Tahun 19992004, bahwa pembangunan hukum harus mewujudkan sistem hukum nasional yang menjamin tegaknya supremasi hukum dan hak asasi manusia berdasarkan keadilan dan kebenaran. ${ }^{18}$

\section{b. Pengaturan Perubahan Anggaran Dasar Yayasan}

Yayasan didirikan dengan akta Notaris dan dibuat dengan bahasa Indonesia, diuraikan dengan jelas pokok-pokok pendirian Yayasan serta berapa besar harta kekayaan dari para pendirinya yang akan dijadikan harta kekayaan awal dari Yayasan tersebut.

Anggaran Dasar merupakan bagian dari isi akta pendirian Yayasan, Anggaran Dasar itu sendiri harus sesuai dengan aturan dasar Yayasan yang wajib dipatuhi oleh pembina, pengurus dan pengawas yang mana Anggaran Dasar tersebut berlaku setelah akta Yayasan tersebut mendapatkan pengesahan dari Menteri Hukum dan Hak Asasi Manusia. ${ }^{19}$

Di dalam Pasal 14 ayat 2 (dua) Undang-Undang Nomor 28 Tahun 2004, Anggaran Dasar Yayasan yang dituang di dalam akta Yayasan memuat antara lain :

a) Nama Tempat Kedudukan.

b) Maksud dan tujuan serta kegiatan untuk mencapai maksud dan tujuan tersebut.

c) Jangka waktu pendirian.

d) Jumlah kekayaan awal yang dipisahkan dari kekayaan pribadi pendiri dalam bentuk uang dan benda.

e) Cara memperoleh dan penggunaan kekayaan.

f) Tatacara pengangkatan, pemberhentian dan penggantian anggota pembina, pengurus dan pengawas.

g) Hak dan kewajiban anggota pembina, pengurus dan pengawas.

h) Tata cara penyelenggaraan rapat organ Yayasan. Ketentuan mengenai perubahan Anggaran Dasar.

i) Penggabungan dan perubahan Anggaran Dasar.

j) Penggunaan sisa hasil likuidasi atau penyaluran kekayaan Yayasan setelah pembubaran.

k) Keterangan lain yang memuat sekurang-kurangnya nama, alamat, pekerjaan, tempat dan tanggal lahir serta kewarganegaraan.

Perubahan substansi Anggaran Dasar dapat di kategorikan menjadi 3 (tiga) kategori :

1. Hal yang tidak boleh dirubah, yaitu maksud dan tujuan Yayasan.

${ }^{18}$ Anwar Borahima, Op.Cit., hlm. 37-38.

${ }^{19}$ Gatot Supramono.(2018). Hukum Yayasan di Indonesia. Jakarta: Rineka Cipta, hlm.48. 
2. Hal yang boleh dirubah dengan mendapat persetujuan Menteri, yaitu nama dan kegiatan Yayasan.

3. Hal yang boleh dirubah cukup dengan diberitahukan kepada Menteri, yaitu perubahan tempat kedudukan Yayasan. ${ }^{20}$

Khusus mengenai perubahan Anggaran Dasar Yayasan yang memerlukan persetujuan Menteri Hukum dan Hak Asasi Manusia maka segala ketentuan yang berkaitan dengan pengesahan Yayasan secara mutatis mutandis berlaku juga bagi permohonan perubahan Anggaran Dasar. Selanjutnya dalam Undang-Undang Yayasan ditentukan pula bahwa perubahan Anggaran Dasar Yayasan tidak dapat dilakukan pada saat Yayasan dinyatakan dalam kepailitan kecuali atas persetujuan kurator. Di dalam Peraturan Pemerintah Republik Indonesia Nomor 63 Tahun 2008 tentang Pelaksanaan Undang-Undang Yayasan ada dua (2) tatacara yaitu :

1. Tata cara pengajuan permohonan pengesahan akta pendirian dan persetujuan akta perubahan Anggaran Dasar terdapat di dalam Pasal 15, Pasal 16 dan Pasal 17.

2. Tata cara pemberitahuan perubahan Anggaran Dasar dan perubahan data Yayasan terdapat dalam Pasal 18 dan Pasal 19.

\section{Dasar Pertimbangan Hakim Dalam Mengadili da Memutus Perkara Sengketa Peruba- han Anggaran Dasar Yayasan (Kajian terhadap Perkara Nomor : 25/PDT.G/2917/PN.Pya)}

Setelah Undang-Undang Nomor 16 Tahun 2001 berjalan kurang lebih tiga tahun, kemudian diubah melalui Undang-Undang Nomor 28 Tahun 2004 yang diundangkan pada tanggal 6 Oktober 2004 dalam Lembaran Negara Republik Indonesia Nomor 4430 dan mulai berlaku sejak tanggal 6 Oktober 2005 yakni satu tahun setelah diundangkan. Sebelum diundangkan Undang-Undang Nomor 16 Tahun 2001, belum ada keseragaman tentang cara mendirikan Yayasan. Pendirian Yayasan hanya didasarkan kepada hukum kebiasaan dalam masyarakat. Untuk menghindari penafsiran dalam penelitian ini, baik Undang-Undang Nomor 16 Tahun 2001 maupun Undang-Undang Nomor 28 Tahun 2004 tentang Yayasan hanya disingkat dengan UU Yayasan saja.

Keberadaan Undang-Undang Nomor 16 Tahun 2001 yang diubah dengan Undang-Undang Nomor 28 Tahun 2004 tentang Yayasan (UU Yayasan), nampak adanya keinginan pemerintah untuk menampung kebutuhan akan pengaturan masalah Yayasan ini.

Prinsip yang ingin diwujudkan dalam ketentuan UU Yayasan adalah kemandirian yayasan sebagai badan hukum, keterbukaan seluruh kegiatan yang dilakukan yayasan, dan akuntabilitas kepada masyarakat mengenai apa yang telah dilakukan oleh yayasan, serta prinsip nirlaba yang merupakan prinsip yang fundamental bagi suatu yayasan.

Hal itu terlihat dari beberapa ketentuan dalam undang-undang tersebut. Misalnya dengan adanya kewajiban pada setiap pendiri yayasan untuk memintakan pengesahan badan hukum kepada Menteri Hukum dan HAM, dan seterusnya setiap ada perubahan mengenai nama dan kegiatan ikhtisar laporan tahunan yang menyangkut keuangan dan kegiatan yayasan dalam tahun yang lampau.

Keinginan pemerintah untuk mengatur dan mengendalikan pendirian dan pengoperasian Yayasan tentunya didasarkan kepada pengalaman di masa lampau, tatkala banyak Yayasan yang menyalahgunakan segala kemudahan yang diberikan kepada Yayasan. Secara praktis, asumsi demikian memang perlu dibuktikan dengan suatu penelitian khusus. Namun secara

${ }^{20}$ Rita M- L \& J Law Firm.(2019). Risiko Hukum Bagi Pembina, Pengawas dan Pengurus Yayasan. Jakarta: Forum Sahabat, hlm. 17 
kualitatif dapat dirasakan dan juga disaksikan berbagai Yayasan yang disalahgunakan untuk kepentingan tertentu, baik untuk kepentingan pribadi maupun kepentingan golongan.

Menurut UU Yayasan, semua Yayasan yang telah berdiri dan didaftarkan di Pengadilan Negeri dan diumumkan dalam Tambahan Berita Negara Republik Indonesia, atau didaftarkan di pengadilan negeri dan mempunyai izin melakukan kegiatan dari instansi terkait tetap diakui sebagai badan hukum, dengan ketentuan dalam waktu paling lambat 5 (lima) tahun sejak dimulai berlakunya undang-undang tersebut wajib disesuaikan Anggaran Dasar.

Dalam Pasal 11 Ayat (1) UU Yayasan disebutkan bahwa, Yayasan memperoleh status badan hukum setelah akta pendirian Yayasan sebagaimana dimaksud dalam Pasal 9 ayat (2) memperoleh pengesahan dari Menteri. Sehubungan dengan bunyi Pasal 11 Ayat (1) ini, berarti sejak didirikannya Yayasan, maka secara otomatis Yayasan tersebut sudah dipenuhi syaratsyarat pendirian Yayasan tersebut yang dutuangkan dalam sebuah akta. Jadi, untuk mengetahui mengenai perubahan Akta Yayasan, dapat dipahami maksud ketentuan dalam Pasal 14 Ayat (1), disebutkan bahwa akta pendirian Yayasan memuat Anggaran Dasar dan keterangan lain dianggap perlu. Sehubungan dengan itu, makna dari Pasal 14 Ayat (1) ini adalah berubahnya akta pendirian Yayasan, harus berubah pula ketentuan-ketentuan dalam Anggaran Dasar Yayasan. Dalam UU Yayasan mengatur mengenai perubahan akta pendirian Yayasan sebelum kelaurnya UU Yayasan, dimana akta pendiriannya harus disesuaikan dengan ketentuan dalam UU Yayasan tanpa terkecuali.

Dalam ketentuan dalam Pasal 37 Ayat (4) UU Yayasan dinyatakan bahwa Pemberitahuan perubahan Anggaran Dasar Yayasan, harus dilampiri:

a. Salinan akta perubahan Anggaran Dasar Yayasan;

b. Tambahan Berita Negara Republik Indonesia yang memuat akta pendirian Yayasan atau bukti pendaftaran akta pendirian di pengadilan negeri dan izin melakukan kegiatan dari instansi terkait;

c. Fotokopi Nomor Pokok Wajib Pajak Yayasan yang telah dilegalisir oleh notaris;

d. Surat pernyataan tempat kedudukan disertai alamat lengkap Yayasan yang ditandatangani oleh pengurus Yayasan dan diketahui oleh lurah atau kepala desa setempat;

Berdasarkan ketentuan di atas, beberapa hal yang harus dilampirkan dalam perubahan akta Yayasan tersebut untuk mewujudkan mekanisme pengawasan publik terhadap Yayasan yang diduga melakukan perbuatan yang bertentangan dengan undang-undang, Anggaran Dasar, atau merugikan kepentingan umum, UU Yayasan mengatur tentang kemungkinan pemeriksaan terhadap Yayasan yang dilakukan oleh ahli berdasarkan penetapan pengadilan atas permohonan tertulis pihak ketiga yang berkepentingan atau atas permintaan kejaksaan dalam hal mewakili kepentingan umum.

Ruang lingkup perubahan akta pendirian Yayasan dapat dilihat dan dipahami apa-apa saja yang dicantumkan dalam Anggaran Dasar. Namun harus memperhatikan ketentuan dalam Pasal 17 yaitu tidak dibenarkan merubah maksud dan tujuan. Selengkapnya disebutkan, "Anggaran Dasar dapat diubah kecuali maksud dan tujuan Yayasan”.

Perubahan nama dan tempat kedudukan. Nama sangat penting bagi Yayasan dengan menggunakan kata "Yayasan" di depan namanya. Sama hal dengan manusia, tidak dapat dilepaskan dari sebuah nama untuk mengetahui identitasnya, sehingga dengan nama itu akan dengan mudah diketahui siapa manusia tersebut. Begitu pulalah sebuah Yayasan jika tidak punya nama akan sulit untuk membedakannya. Lagi pula secara perdata juga mengenal subjek hukum yakni suatu badan atau organisasi yang dianggap dapat bertindak sebagaimana manusia biasa. Dalam pemberian nama terhadap Yayasan pada dasarnya bebas dengan nama apa saja seperti nama orang, nama bunga, nama tanaman, dan lain-lain. Meskipun demikian kebebasan memberikan nama terhadap Yayasan, oleh undang-undang dibatasi dalam Pasal 15 Ayat (1) UU 
Yayasan yakni, Pertama, telah dipakai secara sah oleh Yayasan lain; dan Kedua, bertentangan dengan ketertiban umum dan/atau kesusilaan.

Perubahan jangka waktu pendirian. Jika ingin merubah jangka waktu sampai kapan pendirian Yayasan itu, hanya diberikan oleh undang-undang dua alternatif. Hal tersebut diatur dalam Pasal 16 Ayat (1) UU Yayasan yakni untuk jangka waktu tertentu dan untuk jangka waktu tidak tertentu. Jika waktunya tertentu, maka dengan jelas disebutkan dalam akta maupun dalam perubahan akta pendirian Yayasan misalnya 10 (sepuluh) tahun. Dengan menyebutkan waktu tertentu tersebut, maka setelah tiba waktunya, Yayasan tersebut harus bubar. Namun dalam Ayat (2) diberikan pula waktu perpanjangan jika dikehendaki oleh pendiri. Mengenai jangka waktu tidak tertentu, Yayasan dapat berdiri sepanjang masa walaupun telah bergantiganti organ-oragannya. Perubahan tidak boleh dilakukan pada waktu Yayasan akan pailit. Alasannya bertentangan dengan maksud ketentuan Pasal 1 Angka (1) Undang-Undang Nomor 37 Tahun 2004 tentang Kepailitan. Perubahan akta tersebut harus berdasarkan kepada rapat pembina. Hal ini karena rapat pembina mempunyai kekuasaan yang diamanahkan Pasal 28 Ayat (2) huruf a UU Yayasan bahwa rapat pembina merupakan kedudukan organ tertinggi dalam Yayasan.

Perubahan yang harus mendapat persetujuan Menteri. Yakni menyangkut Pasal 21 Ayat (1) yaitu mengenai nama dan kegiatan Yayasan harus mendapat persetujuan Menteri. Hal ini disebabkan karena nama dan kegiatan Yayasan tersebut sangat berarti secara administratif. Perubahan yang hanya cukup diberitahukan kepada Menteri. Yakni mengenai Pasal 21 Ayat (2), dimana perubahan selain dari pada Pasal 17 dan Pasal 21 Ayat (1) UU Yayasan.

Maksud dan tujuan Yayasan tidak boleh diubah kecuali yang telah disebutkan di atas yaitu sosial, keagamaan, dan kemanusiaan. Memang ada disebutkan sebagai pengecualian yakni dalam ketentuan Pasal 14 Ayat (1) bila dinggap perlu. Akan tetapi hal tersebut diberi batasan oleh bunyi Pasal 17 dimana bahwa dalam mengubah akta beserta Anggaran Dasar Yayasan tersebut, dilarang oleh UU Yayasan untuk mengubah maksud dan tujuan Yayasan itu. Tujuan yang diperbolehkan oleh UU Yayasan adalah hanya untuk sosial, keagamaan, dan kemanusiaan.

Selanjutnya terkait dengan Prosedur perubahan akta pendirian Yayasan harus memperhatikan ketentuan formal dalam UU Yayasan. Yakni Pasal 18 Ayat (1), harus dilakukan terlebih dahulu melalui rapat pembina. Pada waktu rapat pembina harus minimal dihadiri $2 / 3$ dari jumlah anggota pembina. Untuk melakukan perubahan akta pendirian Yayasan tersebut harus dilakukan oleh Notaris dan dibuat dalam bahasa Indonesia.

Kemudian untuk melakukan pengumuman perubahan akta sebagaimana dimaksud dalam Ayat (1) diajukan permohonannya oleh Pengurus Yayasan atau kuasanya kepada Kantor Percetakan Negara Republik Indonesia dalam waktu paling lambat 30 (tiga puluh) hari terhitung sejak tanggal akta pendirian Yayasan yang disahkan atau perubahan AD yang disetujui. Dengan demikian bahwa permohonan pengumuman dalam Tambahan Berita Negara (TBN) Republik Indonesia dapat diajukan secara langsung atau dikirim melalui surat tercatat.

Adapun prosedur perubahan akta Yayasan dapat dilakukan melalui langkah-langkah sebagai berikut:

1. Pendiri atau kuasanya mengajukan permohonan perubahan AD kepada Menteri dengan mengirimkan surat permohonan perubahan $\mathrm{AD}$;

2. PerubahanADtersebutkemudiandisetujuiolehMenteriataupejabatyangditunjuk.Persetujuan perubahan itu, paling lambat dilakukan atau diberikan 30 (tiga puluh) hari setelah permohonan AD diterima. Jika permohonan perubahan AD ditolak, harus diberi tahu secara tertulis kepada pendiri Yayasan. 
Dalam surat permohonan tersebut, wajib melampirkan alasan-alasan penolakan permohonan. Umumnya, alasan penolakan permohonan terkait erat dengan adanya cacat hukum dalam perubahan AD Yayasan.

Perubahan akta pendirian Yayasan setelah keluarnya Undang-Undang Nomor 16 Tahun 2001 junto Undang-Undang Nomor 28 Tahun 2004 tentang Yayasan(UUyayasan) dimaksudkan agar Yayasan yang sudah ada sebelum lahirnya UU Yayasan supaya memiliki status sebagai badan hukum yang sama dengan Yayasan yang didirikan setelah keluarnya UU Yayasan tersebut. Dengan pengesahan Yayasan sebagai badan hukum, maka perbuatan organ-organ seperti pengurus, pembina, dan pengawas, dalam menjalankan tugasnya mengelola Yayasan harus bertanggung jawab atas segala tindakannya berdasarkan pertanggungjawaban layaknya sebuah badan hukum. Perlu dilakukakan pembedaan antara Yayasan yang kekayaannya dari negara atau yang mengelola dana bantuan negara ataupun dana masyarakat dengan Yayasan yang sifatnya pribadi dengan sumber kekayaan dari harta pribadi dan sumber keuangan rutinnya dari sumbangan perusahaan milik pribadi pendirinya.

Dengan demikian pengaturan perubahan anggaran dasar Yayasan sangat tergantung pada apakah yayasan tersebut sudah berstatus sebagai badan hukum atau tidak, jika belum maka wajib melakukan penyesuaian terhadap UU Yayasan, jika sudah berstatuis sebagai hukum, maka jika terjadi perubahan terhadap nama dan pengurus, maka harus melakukan perubahan anggaran dasar yayasan. Adapun dasar pertimbangan hakim dalam mengadili dan memutus perkara terkait dengan sengketa kepengurusan yayasan adalah bahwa setelah Majelis mencermati dalil gugatan para Penggugat bahwa yang menjadi dalil gugatan para Penggugat adalah mengenai adanya perbuatan melawan hukum yang dilakukan oleh para Tergugat atas terbitnya Akta Yayasan No. 16 tertanggal 18 Desember 2015 yang dibuat oleh Tergugat XII (Notaris Halim Nataatmadja) dan pengesahan yayasan dari Tergugat XIII Menteri Hukum Dan Hak Asasi Manusia Republik Indonesia yaitu pada tanggal 11 Desember 2015 dengan No. SK. AHU-0030613.AH.01.04. tentang Pendirian Badan Hukum Yayasan Pondok Pesantren al Ma-Arif Uswatu Hasanah, selanjutnya majelis hakim akan meneliti terhadap bukti surat yang diajukan oleh pihak Tergugat berkaitan dengan Akta Penyesuai dan Perubahan Anggara dasar Yayasan Pondok Pesantren al Ma-Arif Uswatu Hasanah, yaitu bukti T1 s/T11- 10 yaitu berupa Akta Penyesuaian dan Perubahan Anggaran Dasar Yayasan Pondok Pesantren Uswatun Hasanah Tanggal 10 Desember Nomor 26 yang telah mendapat pengesahan pendirian dari Menteri Hukum dan Hak Asasi Manuasi R I tentang pengesahan pendirian Badan Hukum Yayasan Pondok Pesantren Al-Ma'Arif Uswatun Hasanah (Vide bukti surat tertanda t 1s/d 11$11)$;

Oleh karena itu berdasarkan pertimbangan tersebut di atas maka gugatan para Penggugat telah salah menggugat terhadap Akta No 16 tanggal 18 Desember 2015 yang dalam petitumnya dimohonkan untuk dinyatakan cacat hukum padahal akta tersebut adalah sudah dibatalkan oleh Notaris Natatmadja dan Akta Sah atas Penyesuaian dan Perubahan Anggaran Dasar Yayasan Pondok Pesantren Uswatun Hasanah dan kepengurusannya tertuang dalam akta No. 26 tanggal 10 Desember 2015 yang terdapat Lampiran SK nama Yayasan Pondok Pesantren Al- MA'ARIF Uswatu Hasanah, dengan hal ini menyebabkan gugatan para Penggugat kabur maka dengan demikian eksepsi Tergugat I s/d Tergugat XI yang menyakatan gugatan para Penggugat kabur adalah beralasan hukum untuk dikabulkan;

Dengan demikian kedudukan Yayasan sebagai badan hukum akan menjamin adanya kepastian hukum tentang peran dan tanggungjawab masing-masing organ dalam Yayasan. Kepastian hukum merupakan salah satu unsur terpenting dalam hukum, terutama dalam hukum tertulis, karena hukum tanpa adanya suatu kepastian hukum, maka hukum tersebut tidak akan 
ada artinya dan tidak akan dapat digunakan lagi sebagai pedoman dalam setiap tindakan dan perilaku hidup setiap manusia.

Menurut Gustav Radbruch, terdapat dua macam pengertian kepastian hukum, yaitu kepastian hukum oleh karena hukum, dan kepastian hukum dalam atau dari hukum. Hukum yang berhasil menjamin banyak kepastian hukum dalam masyarakat adalah hukum yang berguna. Kepastian hukum oleh karena hukum memberi dua tugas hukum yang lain, yaitu menjamin keadilan hukum serta hukum harus tetap berguna; sedangkan kepastian hukum dalam hukum tercapai, apabila hukum tersebut sebanyak-banyaknya undang-undang. Dalam undang-undang tersebut tidak terdapat ketentuan-ketentuan yang bertentangan (undang-undang berdasarkan suatu sistem yang logis dan praktis). Undang-undang dibuat berdasarkan rechtswerkelijkheid (keadaan hukum yang sungguh-sungguh) dan dalam undang-undang tersebut tidak terdapat istilah-istilah yang dapat ditafsirkan secara berlain-lainan.

Kepastian hukum menghendaki adanya pengaturan hukum yang jelas dalam peraturan perundang-undangan yang dibuat oleh lembaga-lembaga negara yang berwenang, sehingga peraturan-peraturan yang dibuat itu memiliki aspek yuridis yang dapat memberikan suatu jaminan kepastian bahwa hukum berfungsi sebagai suatu peraturan yang harus ditaati.

Dengan adanya kepastian hukum terhadap kelembagaan yayasan, maka secara tidak langsung akan memberi perlindungan hukum baik kepada para pihak sebagai pendiri, maupun kepada pihak ketiga yang terikat hubungan hukum dengan yayasan. Landasan pijak perlindungan hukum bagi rakyat (masyarakat) di Indonesia adalah Pancasila dan UUD Negara Republik Indonesia Tahun 1945 (UUD NRI 1945), karena merupakan dasar idiologi dan falsafah bangsa Indonesia yang menjunjung tinggi nilai-nilai kemanusiaan dengan menempatkan hukum sebagai panglima dan bukan kekuasaan. Penghormatan terhadap hak-hak asasi manusia dan memposisikan bangsa Indonesia sebagai negara hukum menimbulkan konsekuensi yang harus ditaati dan dilaksanakan oleh pemerintah sebagai penyelenggara negara. Philipus M. Hadjon dengan menggunakan konsep barat sebagai kerangka pikir dan landasan pijak pada Pancasila merumuskan prinsip pengakuan dan perlindungan terhadap harkat dan martabat manusia yang bersumber pada Pancasila dan prinsip negara hukum yang berdasarkan Pancasila.

Perlindungan hukum secara gramatikal "perlindungan" berasal dari kata "lindung" yang berarti mendapatkan dirinya dibawah sesuatu supaya jangan kelihatan. Arti perlindungan adalah segala upaya yang dilakukan untuk melindungi subyek tertentu, juga dapat diartikan sebagai tempat berlindung dari segala sesuatu yang mengancam.

\section{KESIMPULAN}

Perubahan akta pendirian Yayasan setelah keluarnya Undang-Undang Nomor 16 Tahun 2001 junto Undang-Undang Nomor 28 Tahun 2004 tentang Yayasan(UUyayasan) dimaksudkan agar Yayasan yang sudah ada sebelum lahirnya UU Yayasan supaya memiliki status sebagai badan hukum yang sama dengan Yayasan yang didirikan setelah keluarnya UU Yayasan tersebut. Dengan pengesahan Yayasan sebagai badan hukum, maka perbuatan organ-organ seperti pengurus, pembina, dan pengawas, dalam menjalankan tugasnya mengelola Yayasan harus bertanggung jawab atas segala tindakannya berdasarkan pertanggungjawaban layaknya sebuah badan hukum. Adapun dasar pertimbangan hakim dalam mengadili dan memutus perkara terkait dengan sengketa kepengurusan yayasan adalah bahwa setelah Majelis mencermati dalil gugatan para Penggugat bahwa yang menjadi dalil gugatan para Penggugat adalah mengenai adanya perbuatan melawan hukum yang dilakukan oleh para Tergugat atas terbitnya Akta Yayasan No. 16 tertanggal 18 Desember 2015 yang dibuat oleh Tergugat XII (Notaris Halim Nataatmadja) dan pengesahan yayasan dari Tergugat XIII Menteri Hukum Dan Hak Asasi 
Manusia Republik Indonesia yaitu pada tanggal 11 Desember 2015 dengan No. SK. AHU0030613.AH.01.04. tentang Pendirian Badan Hukum Yayasan Pondok Pesantren al Ma-Arif Uswatu Hasanah. Oleh karena itu berdasarkan pertimbangan tersebut di atas maka gugatan para Penggugat telah salah menggugat terhadap Akta No 16 tanggal 18 Desember 2015 yang dalam petitumnya dimohonkan untuk dinyatakan cacat hukum sementara akta tersebut adalah sudah dibatalkan oleh Notaris Natatmadja dan Akta Sah atas Penyesuaian dan Perubahan Anggaran Dasar Yayasan Pondok Pesantren Uswatun Hasanah dan kepengurusannya tertuang dalam akta No. 26 tanggal 10 Desember 2015 yang terdapat Lampiran SK nama Yayasan Pondok Pesantren Al- MA'ARIF Uswatu Hasanah, dengan hal ini menyebabkan gugatan para Penggugat kabur maka dengan demikian eksepsi Tergugat I s/d Tergugat XI yang menyakatan gugatan para Penggugat kabur adalah beralasan hukum untuk dikabulkan.

\section{DAFTAR PUSTAKA}

\section{Buku}

Anwar Borahima.(2011).Kedudukan Yayasan di Indonesia : Eksistensi, Tujuan, dan Tanggung Jawab Yayasan. Jakarta: Kencana.

Subekti.( 2013). Pokok-Pokok Hukum Perdata. Jakarta: PT. Inter Masa.

Rachmat Soemitro.(2011). Penuntutan Perseroan Terbatas dengan Undang- undang Pajak Perseroan. Bandung: PT. Eresco.

Wirjono Projodikoro.( 2011). Azas-azas Hukum Perdata. Bandung: Sumur Bandung, hlm. 84. Chatamarrasyid.(2012). Tujuan Sosial Yayasan dan Kegiatan Usaha Bertujuan Laba. Bandung: Citra Aditya Bakti.

Pitlo, Het.(2011). Nederlands Burgelijke Wet Boek deel 1 A, Het Rechts Personenrecht. B.V. Arnhem: Gouda Quint.

Gatot Supramono.(2008). Hukum Yayasan di Indonesia. Jakarta: Rineka Cipta.

C. Ali.(2011). Badan Hukum. Bandung: Alumni.

Anwar Borahima.(2011). Kedudukan Yayasan di Indonesia : Eksistensi, Tujuan dan Tanggung Jawab Yayasan. Jakarta: Kencana.

Rudi Prasetya.(2013). Kedudukan Mandiri Perseroan Terbatas. Bandung: Citra Aditya Bakti.

Boedi Harsono.(2018). Hukum Agraria Indonesia, Sejarah Pembentukan Undang-Undang Pokok Agraria, Isi, dan Pelaksanaannya, Jilid I Hukum Tanah Nasional. Jakarta: Djambatan.

Gatot Supramono.(2018). Hukum Yayasan di Indonesia. Jakarta: Rineka Cipta.

Rita M- L \& J Law Firm.(2019). Risiko Hukum Bagi Pembina, Pengawas dan Pengurus Yayasan. Jakarta: Forum Sahabat.

\section{Perundang-Undangan}

Pasal 1655 KUHPerdata

Pasal 1656 KUHPerdata 